\title{
Tourism and Toponymy: Commodifying and Consuming Place Names
}

\author{
Duncan Light
}

\begin{abstract}
Academic geographers have a long history of studying both tourism and place names, but have rarely made linkages between the two. Within critical toponymic studies there is increasing debate about the commodification of place names but to date the role of tourism in this process has been almost completely overlooked. In some circumstances, toponyms can become tourist sights based on their extraordinary properties, their broader associations within popular culture, or their role as metanyms for some other aspect of a place. Place names may be sights in their own right or 'markers' of a sight and, in some cases, the marker may be more significant that the sight to which it refers. The appropriation of place names through tourism also includes the production and consumption of a broad range of souvenirs based on reproductions or replicas of the material signage that denotes place names. Place names as attractions are also associated with a range of performances by tourists, and in some cases visiting a place name can be a significant expression of fandom. In some circumstances, place names can be embraced and promoted by tourism marketing strategies and are, in turn, drawn into broader circuits of the production and consumption of tourist space.
\end{abstract}

\section{Keywords}

Toponymy, place names, tourist sights, souvenirs, performances, commodification 


\section{Tourism and Toponymy: Commodifying and Consuming Place Names}

\section{Introduction}

Toponymy is the study of place names, a subject which, at first sight, might appear completely unrelated to tourism. Indeed, academic geographers have a long history of studying both tourism and toponymy but have rarely made links between the two. Initially, it might appear ridiculous that something as seemingly insubstantial as a 'mere' name could be of any interest to tourists. However it is clear that, in certain circumstances, names are the object of the tourist gaze. We only have to think of the 'Hollywood Walk of Fame' in Los Angeles. This contains 2,400 metal stars set into the pavement of Hollywood Boulevard, each inscribed with the name of a distinguished figure in the entertainment industry. The Walk is one of the biggest tourist attractions in Los Angeles attracting an estimated 10 million visitors annually (Martin 2010). Certainly there are other things to see and do along the boulevard, but the Walk illustrates how 'mere' names can be a huge draw for tourists and fans. However, it is not only the names of people that can draw tourists: place names can also be attractions. The clearest illustration is the famous 'Hollywood' sign on Mount Lee in California. At its simplest this is a place name and a label which identifies the district of the city. Of course, the Hollywood sign is much more than a place name - it is a signifier for the glamour of the American film industry and has become an American cultural icon in its own right (Braudy 2011). But it has also been a site/sight of pilgrimage for tourists for many decades. Without question, what is one of the most famous place name labels in the world is also one of Los Angeles’ biggest tourist attractions.

Names then - and place names in particular - can have significance for tourists. In this essay I examine the relationship between tourism and toponyms (place names) at a variety of scales and in a range of contexts and I argue that this relationship is more substantial than may at first appear. First, I explore how place names can, in themselves, become tourist sights and I focus on the appropriation and consumption of such names through various tourism practices. Second, I examine the performances of tourists at places that are attractions because of their name. Third, I consider the commodification of place names as tourist souvenirs and I situate my argument within an emerging research focus on the commodification of toponymy within 
'critical' toponymic studies. This paper is intended as a broad-ranging examination of a hitherto little-investigated relationship between tourism and toponymy. It also considers the nature of tourist sights and the broader relationship between sights and their markers. As such, no empirical research data is presented and the examples used are illustrative rather than definitive or paradigmatic (see Azaryahu 1996).

\section{Tourism and (Place) Naming Practices}

Within tourism studies there has been limited analysis of the relationships between (place) names and tourist practices. In his seminal semiotic analysis of tourism MacCannell (1989) identified naming as part of the process of defining tourist attractions. He proposed a process of 'sight sacralization' (p.44) in which objects, places and landscapes are constructed and differentiated as exceptional sights of interest to the tourist. This process involves 'markers' which signpost that something is worth visiting. The simplest form of marker is a name. Thus allocating a name (or appropriating an existing toponym) is the first stage of sight sacralization and in this formulation, place names can function as on-sight markers of the attraction. Moreover, MacCannell also argued that markers (such as place names) could displace the sight itself as the focus of tourist attention. With reference to Paris he illustrated how a street name sign could displace the street as the focus of tourist recognition and, subsequently, representations of that sign (in the form of souvenirs) could become more important to the tourist than the original. MacCannell's work is important for its recognition that names can be of interest to tourists and that such names have a broader role in signifying a tourist site/sight.

Dann (1996) also examined the significance of nomenclature and naming practices in tourism. Citing Boyer and Viallon (1994) he identifies the importance of the names of places, attractions and destinations in creating a product image that will communicate the right message and attract customers. Such names can suggest distinction, originality, authenticity or even romance. For this reason, the names of resorts, attractions and hotels often contain an element of fantasy, adventure, magic or escape. Dann also examines how strategies to reimagine and rebrand places (particularly former industrial towns or regions) to attract tourists frequently involves either changing their names or creating new toponyms that will sound more appealing or 'appropriate' to potential visitors. 
This theme of the appropriateness of names of tourist sites/sights is also discussed by Clark (2009) in the context of indigenous tourism (sites of Aboriginal art) in Victoria, Australia. Many of these sites had been attributed descriptive or locational English names during the 1920s. These, in turn, were important in shaping the expectations of visitors (Morgan (2006) makes a similar point regarding the names of state parks in the USA). However, many visitors found that the sites did not match the expectations generated by the names. The response was disappointment (and in some cases inappropriate behaviour such as vandalism). Clark argued that names were an important (if largely overlooked) aspect of site management and that there was a need to ensure appropriate names (through renaming if necessary) so as to generate realistic expectations among visitors.

Various studies have examined the role of names and naming in the creation of new place identities within broader economic development strategies. For example, in the UK historical and cultural associations have been appropriated in the creation of coherent themed landscapes (Shaw and Williams 2004) that can be promoted to visitors. A key part of this theming involves inventing new names (Urry 1990, Urry and Larsen 2011) that have a resonance with potential visitors and succinctly capture the nature of the tourist experience that is offered. These contrived toponyms are then attached to a broader area through place marketing initiatives. Some of the earliest examples involved literary associations (Rojek 1993) such as Bronte Country or Thomas Hardy Country. Similarly Daphne Du Maurier Country and Catherine Cookson Country are derived from popular fiction. Other examples are drawn from heritage associations (Prentice 1994) such as Robin Hood Country or 1066 Country. Many more have associations with popular culture, particularly television. These include Last of the Summer Wine Country or Emmerdale Country in the UK (Urry 1990).

Other recent research has explored the significance of (place) naming practices in mass tourism destinations. Andrews $(2005,2010)$ examines the predominantly English names (such as The Coach and Horse Inn or The Kings Arms) attributed to bars and clubs in Spanish resorts that cater for a predominantly British clientele. Such names reinforce a sense of familiarity (rather than difference) by reassuring visitors that the destination is not too far (or different) from home. In a context where the notion of a clear demarcation between holiday and home is increasingly questioned (Franklin 2003; McCabe 2002; Hannam and Knox 2010), naming can be used to emphasise the continuities between home and away. 
Overall, while the tourism literature has little to say about place names, the academic literature about toponymy has even less to say about tourism (Shoval 2013). There is a long tradition within the disciplines of geography and history of studying toponymy and naming practices. Much of this work has been descriptive and encyclopaedic with a focus on relating toponyms to patterns of settlement during different historical periods. Unsurprisingly, tourism is almost entirely absent from such accounts. More recently a new approach to the study of place names has emerged, known as 'critical toponymies' (Berg and Vuolteenaho 2009). This perspective refuses to treat place names and naming practices as neutral, innocent or apolitical. Instead, the focus is on the political and cultural choices involved in attributing - or not attributing - a place name. Critical toponymic studies focuse both on the ways in which naming places is an integral component of modern governamentality (Rose-Redwood et al 2010) and also on the role of commemorative names in the construction of collective memory (Azaryahu 1996, Vuolteenaho and Berg 2009).

Within the critical toponymies literature there are isolated references to tourism by some of the more insightful contributors. For example, there is recognition that commemorative toponyms can, in themselves, be of interest to tourists (see for example Alderman 2006). One study that makes an explicit link between place names and tourism development is Shoval's analysis (2013) of the Old City of Acre in Israel. Here names were attributed to streets by the Israeli authorities as part of a strategy to promote tourism in the city. Such naming was intended to produce a coherent urban landscape that visitors could easily navigate. However, these names are largely unknown or ignored by local (predominantly Arab) residents of the city who, instead, use their own names for the streets (which have largely been passed on through oral traditions rather than being formally inscribed onto the urban landscape). There was, therefore, a mismatch between the names used by visitors and local people. This study is important for demonstrating how tourism is implicated in broader tensions surrounding the attribution of names to urban places. However, it says little about the significance of place names for tourists themselves, or the ways that they engage with place names during their holiday-taking.

A recent development within critical toponymic studies is a focus on the economic rather than the political roles of place names. In particular, there is increasing interest in 'toponymy as commodity' (Rose-Redwood and Alderman 2011). To date most attention has focused on 
the commodification of place-naming rights, where public authorities opt to sell these rights to corporate sponsors (Rose-Redwood et al 2010, Rose-Redwood 2011, Rose-Redwood and Alderman 2011). This is certainly an important research agenda but there are other aspects of the commodification of place names that also merit attention. In this paper I seek to contribute to (but also broaden) this debate through a consideration of tourism. In particular, I examine a range of ways in which place names are commodified by - and for - diverse practices of tourism and tourists.

\section{(Consuming) Place Names as Tourist Sights}

Many toponyms are of little interest to tourists beyond their use within wayfinding strategies in an unfamiliar destination (see for example Chang 2013). However, in some cases a place name can be a sight in its own right. Urry and Larsen (2011) argue that the principal characteristic of a tourist sight is that it is, in some way, out of the ordinary (see also Urry 1990). Similarly, Rojek (1997:52) defines a tourist sight as 'a spatial location which is distinguished from everyday life by virtue of its natural, historical or cultural extraordinariness'. In this context some toponyms are sufficiently unusual or extraordinary to be of interest to tourists. The best examples are those that are exceptional because of their length. At 85 characters the longest toponym in the world is Taumatawhakatangihangakoauauotamateaturipukakapikimaungahoronukupokaiwhenuakita natahu in New Zealand. The name designates a hill in the Maori language. It is clearly marked as a tourist sight: the name is inscribed on a large sign at the side of the road for visitors to stop and observe, while advance signs inform visitors that the name is ahead. The second longest toponym is Llanfairpwllgwyngyllgogerychwyrndrobwllllantysiliogogogoch in North Wales, UK. This Welsh-language place name is inscribed in full on various buildings in the centre of the village and on the platform of the town's railway station (see Figure 1). The third longest toponym is Chargoggagoggmanchauggagoggchaubunagungamaugg in Massachusetts, USA. This is the name of a lake in a Native American language and is a minor tourist attraction within the region. 
Figure 1: Place name sign (with pronunciation guide) at Llanfairpwllgwyngyllgogerychwyrndrobwllllantysiliogogogoch

In other instances a place may gain celebrity simply because its name is unusual or surprising. Some of the best known examples include Hell (in Norway and in several American states), Condom (France), Shitterton, Booze and Crackpot (all UK), Truth or Consequences and Mars (USA) and Fucking (pronounced Foo-king) (Austria). Such words are not, of themselves, extraordinary: indeed, many are in widespread daily use. Instead, it is their attachment to places and their role as toponyms that is incongruous and therefore an object of curiosity. However, such toponyms only have meaning within the context of a particular language (English in this case): a name like Fucking has no vulgar connotations in the German language, while the word ‘condom’ does not exist in French. What makes a toponym the focus of tourist interest depends therefore on the positionality of the people who visit it. This, in turn, illustrates how the significance of tourist sights is culturally constructed within the culture (and language) of origin of the tourist (Craik 1997) rather than deriving from inherent qualities of the destination.

However, while unusual place names may attract visitors, the settlements associated with the names often contain little out of the ordinary. A similar situation can arise with former battlefield sites that have been returned to agricultural use: there is often little of interest for visitors beyond the name. In situations like these the attention of tourists frequently turns to visual and material representations of the place name (usually the signage on which the name is inscribed). These representations of the toponym constitute 'markers' in MacCannell's formulation. Indeed, they illustrate how the sight and the marker can, in some circumstances, be effectively the same thing: there is no sight beyond the marker (see also Culler 1990). Therefore it is the marker - the signage - that is important in affirming and validating the visit. As such the place name signage (the most commonplace and banal of objects) becomes the principal focus of tourist interest and the setting for a range of activities and performances.

Extraordinary or unusual place names certainly attract visitors but, in other circumstances, ordinary or unexceptional toponyms can do likewise. In such cases, it is the cultural significance of something associated with the toponym that makes it extraordinary. The best 
examples are odonyms (street names) such as Penny Lane in Liverpool. Here the name itself is commonplace but its significance arises from its association with the Beatles (Penny Lane was the title of one of the band's hits in 1967). This association draws Beatles fans from all over the world on a form of secular pilgrimage (on the nature of such pilgrimages see Alderman (2002) and Kruse (2003)). Despite its ordinariness Penny Lane is an established part of the Liverpool Beatles trail (see Kruse 2005) and is regularly visited by tour buses. The iconic status of this name was apparent in the reaction to a proposal in 2006 to rename streets in Liverpool that commemorated figures active in the slave trade. One of these streets was Penny Lane, named after the slave trader James Penny (Glendinning 2006). The extensive coverage of the issue in the local, national and international press resulted in the proposal being swiftly dropped. Another street name associated with The Beatles is Abbey Road in London. This was the title of the band's last album (and is pictured on the album cover). Today Abbey Road receives a constant stream of visitors (particularly at the pedestrian crossing featured on the album cover). As streets Penny Lane and Abbey Road are both unremarkable (both are suburban, residential thoroughfares). Consequently, tourists turn to the signs (the 'markers') that identify the streets which offer the only distinctive 'sight' to affirm their visit.

The examples of Penny Lane and Abbey Road illustrate how some toponyms can themselves be conceptualized as a form of (intangible) heritage and the contemporary consumption of such names can be considered as a form of heritage tourism. In many cases, the name attached to an historic object is as meaningful to the visitor as the object itself. One of the best examples is Route 66 in America, a long distance highway which opened in 1926. Although the route was superseded by the interstate highway system it has become something of a cultural icon within America and has been recognized and protected as a historic landmark since the 1980s. Today it is a significant heritage attraction, receiving thousands of visitors from around the world (Caton and Santos 2007). The attraction itself is a road and many visitors take the opportunity to drive part of it. However, an inseparable part of the attraction is the iconic black-and-white signage containing the name Route 66. These identify the road but also signify it as a tourist attraction and validate the experience of visiting. They are consequently one of the most frequently photographed features of the road. Another place name enjoying heritage status is Carnaby Street in London. This was a centre of fashion and style during the 1960s and the street continues to attract visitors for this reason. 
There are many other examples of place/street names that have been 'sacralized' through popular culture. These include toponyms that featured in cinema such as Sunset Boulevard and Mulholland Drive (both in Los Angeles) and Miracle on $34^{\text {th }}$ Street (New York).

Whether filming took place on the eponymous streets is not relevant since film tourists seek the places represented in a film and not the location where filming took place (Roesch 2009). Other place names that are celebrated within popular culture include $42^{\text {nd }}$ Street (a musical set in New York) and Mornington Crescent (a station on the London Underground which features in a popular British radio comedy show). Similarly Baker Street in London is famed as the (fictional) address of Sherlock Holmes and draws fans from all over the world. While visitors come to see the street rather than the name, representations of the name can play an important role in validating the visit.

In other instances, toponyms that are unexceptional in themselves may enjoy an enhanced significance for tourists because they are metonymic for some other aspect of a destination, landscape or city. For example, Broadway is the name of a street in New York, but it is also the centre of theatre and musicals in the city. Wall Street signifies the financial centre of New York while Whitehall in London is the centre of government in the UK. Other street names evoke a particular way of life or historical era. Haight-Ashbury, a district of San Francisco, USA (named after the intersection of two streets) is associated with the hippie culture of the 1960s and bohemian living more generally. Again, the name itself is rarely of interest to tourists but is important as a marker or signifier of something else that constitutes the attraction. As in other examples, tourist interest can turn to material representations of the name, particularly if there are few obvious 'sights’ along the thoroughfare.

Place names can also be of interest to tourists because of their associations with prestige, social status, or judgements of good taste. For example, Bond Street in London, Avenue des Champs-Élysées in Paris, Fifth Avenue in New York and Rodeo Drive in Los Angeles are renowned and prestigious locations for high-end shopping and attract tourists for this reason. In addition they also attract visitors who do not go to shop but simply to enjoy being in a place associated with exclusivity, glamour and sophistication. In cases such as these the toponym represents a form of symbolic capital (Alderman 2008; Alderman et al 2012) that is strongly associated with both place distinctiveness and social distinction. Through practices of tourism the symbolic capital which inheres in the place name is converted to economic capital by both local entrepreneurs and multinational companies. 
In many cases toponyms may gain popularity with tourists without any intervention by tourism planning or promotion agencies. However, in other places such agencies actively participate in the production of the name as a tourist site within local economic development strategies. One example is the small town of Vulcan in Canada (Mair 2009). Originally dependent on wheat production, by the late twentieth century the town faced the need to develop alternative economic activities. Some members of the local community pushed for the development of a ludic form of tourism themed around the town's name and its appeal for Star Trek fans. In this case the toponym represented a particular form of symbolic capital with a powerful appeal to a specific group of fans. This strategy proved successful, demonstrating how a place name can be the catalyst for a significant transformation of space in the image of themed/niche tourism. In a similar vein the Scottish village of Dull and the American town of Boring instituted a formal pairing arrangement intended to encourage tourists to visit both places on account of their names (BBC 6 June 2012).

Such is the power of toponyms to attract tourists that new names can be deliberately contrived for this purpose. One of the earliest (and most celebrated) examples is, again, Llanfairpwllgwyngyllgogerychwyrndrobwllllantysiliogogogoch in North Wales. This unremarkable village was originally known by its Welsh name of Llanfairpwllgwyngwll. The name was artificially extended in the 1850s by a local entrepreneur purposefully to create the longest place name in Britain. This, in turn, created something unusual for tourists to see and gave them a reason to stop there. The name remains the village's main (and only) claim to fame.

In other instances, existing toponyms can be changed in order to attract visitors. In Melbourne, Australia a small street was renamed ACDC Lane in 2004 after the heavy metal band which had close associations with the city (Frost 2006; 2008). Although fans were drawn to Melbourne there was no obvious focal point for their interest. Within a strategy to diversify its offering for tourists and exploit its heritage of popular culture the city council opted to rename an inconspicuous central street (Corporation Lane) after AC/DC to create something for fans to visit. There is little to see on the street beyond the plates featuring the name (although the street also hosts open-air festivals and music parties). As such, the name is effectively the marker of a non-existent attraction. Another prominent example of renaming is the Tibetan county of Zhongdian which was renamed Shangri-La in 2002 with 
the endorsement of the central Chinese authorities (Kolås 2004). This name is inspired by James Hilton’s 1933 novel Lost Horizon which portrayed Shangri-La as an idyllic mountain valley, largely isolated from the outside world. Over time, Shangri-La has come to represent an archetypal rural paradise and has become a powerful cultural myth of Otherness. By renaming the region in this way the local authorities were seeking to boost tourism in a region with limited other economic opportunities.

On the other hand, renaming places to exploit the symbolic capital of their names does not always enjoy local support. A good example is Mount Airy in North Carolina, USA (Alderman et al 2012). This small town has enthusiastically promoted itself to tourists as 'Mayberry' after the location of a popular television show of the 1960s (the lead actor of which grew up in Mount Airy). The townscape has been significantly transformed to more closely represent Mayberry; more than 30 local businesses use Mayberry in their names; and the town hosts an annual 'Mayberry Days' festival. However, although visitors (and some local people) proposed formally renaming the town as Mayberry this was seen as a step too far by the local authority which strongly opposed the suggestion.

\section{Tourist Performances of Place Names}

All tourist sites/sights are associated with particular practices or 'performances' by their visitors (Edensor 2000, 2001, Franklin 2003, Bærenholdt et al 2004) and place names are no exception. Moreover, since the performances of tourists play an important role in reproducing the meanings of tourist spaces and places (Edensor 2001) the activities and practices of 'place name tourists' are instrumental in reconstituting the symbolic meaning and significance of particular toponyms and re-sacralising them as 'attractions'.

Foremost among such performances is photography (Bærenholdt et al 2004; Urry and Larsen 2011). Place names are primarily visual attractions and lend themselves to familiar practices of photography. The representation of a place name on some form of signage provides a convenient and unambiguous opportunity for making a photographic record of the visit. Place name signage is often easy to frame and photograph, particularly since it is often in the same proportions as a camera's viewfinder. Thus, tourists frequently pose for photographs standing 
beside a place name sign. In some locations, tourist photography of place names is clearly choreographed (see Edensor 2000). For example, at

Llanfairpwllgwyngyllgogerychwyrndrobwlllantysiliogogogoch various signs containing the name are placed close to the main car park in the centre of the village (and are notable by their absence elsewhere in the settlement). Some versions of the sign include an English translation. Tourists congregate at these locations to take (and pose for) photographs. Moreover, in their roles as 'markers' of attractions place name signage can provide a convenient focus for photography. For example, visitors to Penny Lane find little that is photogenic in this unremarkable street, so that a photograph of the street name sign will substitute as a visual memento of the visit. In some instances, tourist performances are directly derived from the place name. Thus some tourists at Fucking pose for photographs semi-naked or simulating intercourse, much to the disquiet of local residents (Day 2012). Moreover, many photographs of place names enjoy a wider circulation through being uploaded to photo banks or shared on social networking sites (Urry and Larsen 2011). For example, in March 2013 there were more than 470 photographs on Flickr of the name Llanfairpwllgwyngyllgogerychwyrndrobwllllantysiliogogogoch on various forms of signage. The uploading and circulation of photographs in this way enhances the status and popularity of particular toponyms and reproduces their significance as tourist sights.

Other performances include various acts of writing and graffitiing on the material signage that identifies the place. This is particularly prevalent at place names associated with popular culture (and entirely absent at other locations). Some of the best examples are the toponyms associated with the Beatles (particularly the street name signs for Abbey Road and Penny Lane, and the gate post containing the name Strawberry Field). Here fans have inscribed their names and sometimes place of origin, or have written short messages expressing their appreciation of the band (see Figure 2). Similar practices can be observed at other sites associated with iconic figures from popular culture.

Such graffitiing might initially appear to be mindless vandalism (and is often treated as such by local authorities). However, Alderman (2002) argues that this is a far more meaningful social practice that demonstrates both agency and authorship among visitors (see also SatherWagstaff 2011). Acts of graffitiing constitute a means through which visitors 'connect' with - and, in turn, reconstitute - the memory of figures from popular culture whom they admire. It also acts to further sacralize the sight and identify it as something worth seeing. Moreover, 
reading the graffiti written by other visitors can be an important act of social remembrance at such places (Sather-Wagstaff 2011). Such graffiti does not appear to detract from the experience of visitors: indeed, Brabazon (2002) argues that the graffiti on the Abbey Road street signs enhances the sense of anticipation of visiting the location. Moreover, where there is little else to see, graffiti-covered signage affirms to visitors that they are in the right place and that this is indeed the sight they have come to see

Figure 2: Grafitti on a Penny Lane street sign in Liverpool (itself painted on a wall to avoid theft)

A third form of performance associated with toponyms takes the form of speaking proclaiming - the name itself. Although they are primarily visual, place names also have a sonic and audible dimension: they are heard as well as seen. This dimension of toponyms is particularly apposite in the case of long or unusual names where the pronunciation is not selfevident. Here visitors will often attempt the challenge of pronouncing the name. This can be a social activity where the different members of a group take turns to pronounce the name for the amusement of their peers. Alternatively, parents often attempt to speak the name aloud for their children. In some instances, assistance is provided for visitors (representing another example of stage management of the tourist experience). For example, at Llanfairpwllgwyngyllgogerychwyrndrobwllllantysiliogogogoch the name sign on the platform of the railway station also includes an approximate English phonetic pronunciation of each of the Welsh syllables (see Figure 1). Visitors often congregate on the opposite platform and attempt to read out the name. As Kearns and Berg (2009) argue the performative utterance of a name is a constitutive act that reproduces the meaning and significance of the name itself. Thus, attempting to pronounce a toponym is itself a practice that reconstitutes that name as something out of the ordinary.

\section{(Consuming) Place Names as Souvenirs}

Such is the iconic status of some toponyms that the markers (or other representations) of those names can be highly valued. For this reason, the signage that marks certain place names 
is frequently stolen. For example, in Liverpool the Penny Lane street sign was stolen so often that the local authority resorted to painting a replica of the standard street name plate on a wall (see Figure 2). Stronger and more resistant signage was subsequently installed. After repeated theft of the sign at the entrance to the village of Shitterton in southern England the local authority refused to fund further replacements. Consequently the villagers paid for a heavy block of local stone onto which the village's name was inscribed (Adams 2010). These examples illustrate how the objects that mark a particular place name have material and symbolic value as prized mementos of the visit to that place. These are 'authentic' objects (rather than souvenirs created for tourist consumption) that are available in limited numbers and which are difficult to obtain. Possession (even if illegally) of a genuine place name sign confers a certain status upon the owner (and can represent a form of cultural capital). The stolen object can affirm the seriousness of the owner's fandom, or can testify to the lengths to which the owner was prepared to go in order to own an original object.

In many other instances toponyms are deliberately commodified for tourist consumption in the form of souvenirs. There is abundant demand by tourists for material representations of unusual/famous street names and various forms of merchandise have been developed in response. The most common place name souvenir (particularly for the long or incongruous place names discussed earlier) is a postcard. In Hell (Norway) tourists can send a 'postcard from Hell' (one of the performative rituals associated with a visit to the village) and a similar opportunity is available in Mars (Pennsylvania). In Liverpool visitors can purchase postcards containing a replica of the Penny Lane sign, and others featuring representations of the four (otherwise unexceptional) streets named after the members of The Beatles. On the other hand, some places (such as Fucking in Austria) are reluctant to exploit their name and have made little effort to provide postcards or other souvenirs for visitors.

Another popular souvenir takes the form of replicas of the signage that denominates a particular place or street. The best example is reproduction street name plates. In London replica name plates are available for most of the major thoroughfares and squares in the city centre. These range from full size metal versions (retailing at up to $£ 500 / c \$ 750$ ) to miniature (magnetic) versions. Similarly in Liverpool and the surrounding area of north-west England full-size reproduction (plastic) name plates are available for the streets (Anfield Road and Gwladys Road) that are the addresses of the city's two football clubs. Similar plates 
(featuring the name 'Sir Matt Busby Way', the address of Manchester United Football Club) are available in Manchester.

A further commonplace souvenir is the fridge magnet and these frequently reproduce (or mimic) the design of street name plates. In London most of the central streets are again available as fridge magnets. Similarly, in Paris visitors can purchase replicas of many of the city’s distinctive street name plates as fridge magnets, while in Berlin reproductions of the name plates that mark the entrance to the city for car-borne traffic (black text on a yellow background) are similarly available, as are many of the iconic streets in the city centre (featuring a Gothic font). In Liverpool replica Penny Lane signs are sold as fridge magnets. On some heritage railways in the UK replica station name signs (in 1950s style) are similarly available. Other place name souvenirs include mugs, carrier bags, key rings, badges, T-shirts, mouse mats, pencils and car stickers.

Banal souvenirs such as these are frequently derided as 'kitsch' and dismissed as insignificant. However, recent analysis (Binkley 2000; Atkinson 2007) has argued that socalled kitsch has far more significance for its users than is often recognized. In this context it is important to understand the meaning and importance of such souvenirs for their purchasers. Souvenirs are attempts to capture and retain the unique qualities of a destination (Swanson and Timothy 2011). The purchase of souvenirs is part of the performative 'memory work' (Bærenholdt et al 2004) that is central to most holidays. Their role is to 'store' and materialize memories of a short-lived holiday and to keep it magically alive when the tourist returns home (Haldrup and Larsen 2006). Souvenirs are also attempts to capture and celebrate the unique qualities of place and they play a significant role in triggering an imaginative connection with a place even after the holiday is over (Swanson and Timothy 2011). Indeed, Ramsey (2009) argues that almost any object can play the role of a souvenir if it is able to forge a connection with a place in the mind of its owners. In this context, place name souvenirs can trigger remembrance of a destination as effectively as any other souvenir.

What is significant about place name souvenirs is that they are normally representations or reproductions of the most ordinary and commonplace of objects: place (or street) name signage. Such, reproductions can evoke the extraordinary qualities of a holiday destination as effectively as 'authentic' tourist art or handicrafts (see Peters 2011). It is also important to note that many places have unique or iconic forms of toponymic signage that can be an 
important element of local place identity. For example, the colourful street name plates of Paris (white text on a blue background with a green border) are as evocative (and representative) of the city as the Eiffel Tower or the Arc de Triomphe. The development of souvenirs based on place/street name signage is therefore one component of the broader commodification of place through tourism practices.

In addition, like any commodity, souvenirs are a means of self-expression (Morgan and Pritchard 2005). In contemporary societies personal identities are widely constructed through practices of consumption which includes the nature and activities of holiday-taking. In this context, souvenirs can be used to say something about the person who buys them. They are expressions or statements of a person's individuality, sense of self-identity, creativity and aesthetic taste (Swanson and Timothy 2011). The decision to purchase a souvenir based on a place name (and its subsequent placement in the home (see Peters 2011)) can make a statement that the purchaser wants to identify him/herself with the ordinary and everyday rather than the extraordinary and exotic. It can also declare an allegiance with the urban and a disinterest in supposedly more 'authentic' souvenirs. Similarly it can indicate a desire for a slightly unconventional memento to demonstrate an appreciation of place that goes beyond the conventional 'sights'. Therefore, in various ways, place name souvenirs are absorbed into broader practices and circuits of consumption and self-definition.

\section{Conclusion}

This essay has examined the relationship between tourism and toponyms in a variety of contexts and at a variety of scales. Most place names are unexceptional and consequently are of little interest to tourists. However some toponyms are out of the ordinary - either because of their length, their incongruity, their specific cultural associations, their broader metonymic significance, or the symbolic capital they represent - and these can become the focus of tourist interest. I would not suggest that place name tourism is a distinct form of niche tourism (except, perhaps, among a very small number of diehard enthusiasts). Instead, visits to place name sights usually takes place within broader practices of heritage tourism, cultural tourism, urban tourism, and rural tourism. The appeal to tourists of particular toponyms may, in turn, be exploited by tourism planning and marketing agencies (and by numerous privatesector providers of souvenirs) so that the name is incorporated into the broader circuits of 
production, exchange and consumption that are part of contemporary tourism (cf Ateljevic 2000).

The emergence of place names as tourist attractions illustrates various trends in contemporary tourism. First, such attractions demonstrate the continuing diversification and specialisation of the tourist gaze (Urry 1990; Urry and Larsen 2011) as tourists seek out new and unusual sights which, in turn, are commodified by a range of tourist agencies and actors. Indeed, the case studies discussed here aptly support MacCannell’s claim (1999) that, in contemporary societies, almost anything is potentially a tourist sight. At the same time, place names complicate the distinction between the everyday and the extraordinary that is assumed to lie at the heart of contemporary tourism. Toponyms may be visited and consumed for their extraordinary associations or meanings, but the places associated with such names are frequently unexceptional. Moreover, the signage that identifies such places is often the most everyday of objects. This, in turn, illustrates the blurring between holiday and home, and between the everyday and the touristic, that is subject to increasing academic scrutiny (McCabe 2002; Franklin 2003; Hannam and Knox 2010).

Place names as attractions are also distinctive in semiotic terms. In MacCannell's formulation names can be both sights in their own right (such as Abbey Road or the Hollywood Sign) and also markers of other sights (such as Route 66 or Fifth Avenue). In many instances the name (marker) is of more significance than the sight to which it refers. Indeed, while a toponym may be unusual in some way, the place (or location) that it denominates may offer little of interest to tourists. In such cases the marker becomes (or can substitute for) the sight. In turn, the attention of visitors is centred on the markers (particularly the material representations of a toponym). These are also the settings for tourist performances such as photography or graffitiing that, in their turn, reproduce the significance of the name as a site/sight of interest for tourists.

There are a number of opportunities for further research into the tourism-toponymy relationship that can contribute to wider debates within both tourism studies and critical place name studies. Future research might focus on three main issues. First, there is an opportunity to contribute to the debate within critical place name studies about the commodification of toponymy through focusing on the appropriation of place names within place branding and marketing projects. As the case of Vulcan illustrates, places are increasingly willing to exploit the symbolic capital of their name if it gives them some sort of economic advantage. On one 
hand there is a need for more case study research into this issue and the ways in which placename based tourism contributes to local economic development. In addition, there is also scope to explore broader issues about who makes the decisions to promote such tourism and the extent to which such strategies involve the support of the wider local community. Just as naming itself is a practice that can empower or disenfranchise particular groups (Alderman and Inwood 2013) so too is the exploitation of a place name for tourism. This, in turn, raises broader issues of social justice within local communities. Where there are proposals to change a settlement's name entirely these matters assume even greater prominence.

A second, related, theme is the nature of interactions between tourists and local people in those places that are famous for their names. This links to long-standing debates about the nature of host-guest relations. There are various scenarios. In some instances (such as Fucking in Austria) place-name tourists are unwelcome and are not encouraged. In other cases, a place's name may generate particular expectations among visitors that the place itself does not match so that visitors experience disappointment (Transylvania is one of the best examples). Another scenario is where, through the activities of local tourism entrepreneurs, a place is gradually transformed and commodified to meet the expectations of visitors but to the extent of undermining local senses of place and belonging, and causing tension among local people (Alderman et al 2012). Still more tensions can arise when tourists use different place names from those used by local people (Shoval 2013). On the other hand, as Mair (2009) argues in the case of Vulcan, to talk of a simple dichotomy between hosts and guests is misleading since neither group is homogeneous but instead they comprise a range of positions and interests. There is, therefore a need to embrace more nuanced and fluid conceptions of the host-guest encounter and place-name tourism is one scenario where these issues can be further explored.

Finally, there is much scope to focus on the tourists themselves who visit places that are famous for their names. It is clear that for many visitors the encounter with such a place is often a significant and meaningful experience. This is particularly the case with place names associated with iconic figures or events from popular culture, where the visit can be an occasion to express fandom or engage in acts of remembrance and appreciation. As such, what tourists 'do' at such places is far from trivial: instead they are engaged in purposeful acts of meaning-making. Previous studies such as Alderman (2002) and Sather-Wagstaff (2011) have demonstrated the significance of practices such as graffitiiing and photography when visiting places of memory. There is an opportunity explore such performances in more 
detail, with particular reference to the ways that they involve the material signage which denominates place. In this way, tourist practices can illuminate much broader issues of fandom, celebrity culture and popular memory. Overall, then, place names represent a distinctive lens through which to examine (and develop a richer understanding of) the production and consumption of place for contemporary tourism and tourists.

\section{References}

Adams, S. (2010) Shitterton and a sign of the times, Daily Telegraph, 23 July. Available at www.telegraph.co.uk (accessed 12 March 2013).

Alderman, D.H. (2002) Writing on the Graceland Wall: On the importance of authorship in pilgrimage landscapes, Tourism Recreation Research, 27(2), pp.27-33.

Alderman, D.H. (2006) Naming streets for Martin Luther King, Jr.: No easy road. in: R.Schein (Ed.) Landscape and Race in the United States (pp.213-236). New York: Routledge.

Alderman, D.H. (2008) Place, naming and the interpretation of cultural landscapes. in: P.Howard and B.Graham (Eds.) The Ashgate Companion to Heritage and Identity (pp.195213). Aldershot: Ashgate.

Alderman, D.H. and Inwood, J. (2013) Street naming and the politics of belonging: spatial injustices in the toponymic commemoration of Martin Luther King Jr, Social and Cultural Geography, 14(4), pp.211-233.

Alderman, D.H., Benjamin, S.K. and Scheider, P.P. (2012) Transforming Mount Airy into Mayberry: Film-induced tourism as place-making. Southeastern Geographer, 52(2), pp.212239.

Andrews, H. (2005) Feeling at Home: Embodying Britishness in a Spanish charter tourism resort, Tourist Studies, 5(3), pp.247-266.

Andrews, H. (2010) Contours of a nation: Being British in Mallorca, in: J.Scott and T.Selwyn (Eds.) Thinking Through Tourism, pp.27-50 (Oxford: Berghahn).

Ateljevic, I. (2000) Circuits of tourism: Stepping beyond the 'production/consumption' dichotomy, Tourism Geographies, 2(4), pp.369-388. 
Atkinson, D. (2007) Kitsch geographies and the everyday spaces of social memory, Environment and Planning A, 39(3), pp.521-540.

Azaryahu, M. (1996) The Power of Commemorative Street Names, Environment and Planning D, 14(3), pp.311-330.

Bærenholdt, J., Haldrup, M., Larsen, J. and Urry, J. (2004) Performing Tourist Places (Aldershot: Ashgate).

BBC (6 June 2012) Boring in Oregon votes to pair with Dull in Perthshire, Available at http://www.bbc.co.uk/news/uk-scotland-tayside-central-18336146 (accessed 10 April 2013).

Berg, L. and Vuolteenaho, J. (Eds.) (2009) Critical Toponymies: The Contested Politics of Place Naming (Aldershot: Ashgate).

Binkley, S. (2000) Kitsch as a repetitive system: A problem for the theory of taste hierarchy, Journal of Material Culture, 5(2), pp.131-152.

Boyer, N. and Viallon, P. (1994) La Communication Touristique (Paris: Presses Universitaires de France).

Brabazon, T. (2002) We're one short for the crossing: Abbey Road and popular memory, Transformations 3 (June) pp.1-16. Available at www.transformationsjournal.org (accessed 6 March 2013).

Braudy, L. (2011) The Hollywood Sign: Fantasy and Reality of an American Icon (New Haven CT: Yale University Press).

Caton, K. and Santos, C.A. (2007) Heritage Tourism on Route 66: Deconstructing Nostalgia, Journal of Travel Research, 45(4), pp.371-386.

Chang, H-H. (2013) Wayfinding strategies and tourist anxiety in unfamiliar destinations, Tourism Geographies, 15(3), pp.529-550.

Clark, I.D. (2009) Naming sites: Names as management tools in indigenous tourism sites An Australian case study, Tourism Management, 30(1), pp.109-111.

Craik, J. (1997) The culture of tourism, in: C. Rojek and J. Urry (Eds) Touring Cultures: Transformations of Travel and Theory, pp.113-136 (London: Routledge).

Culler, J. (1990) Framing the Sign: Criticism and its Institutions (Norman: University of Oklahoma Press).

Dann, G. (1996) The Language of Tourism: A Sociolinguistic Perspective (Wallingford: CAB International).

Day, M. (2012) Austrian village F---ing to vote on name change, Daily Telegraph, 17 April. Available at http://www.telegraph.co.uk/news/newstopics/howaboutthat/9209343/Austrianvillage-F-ing-to-vote-on-name-change.html (accessed 12 March 2013). 
Edensor, T. (2000) Staging tourism: Tourists as performers, Annals of Tourism Research, 27(2), pp.322-344.

Edensor, T. (2001) Performing tourism, staging tourism: (Re)producing tourist space and practice, Tourist Studies 1(1), pp.59-81.

Franklin, T. (2003) Tourism: An Introduction (London: Sage).

Frost, W. (2006) Rock music and tourism: The making of ACDC lane, Tourism, Culture and Communication, 6(3), pp.215-216.

Frost, W. (2008) Popular culture as a different type of heritage: The making of AC/DC Lane, Journal of Heritage Tourism, 3(3), pp.176-184.

Glendinning, L. (2006) Renaming row darkens Penny Lane’s blue suburban skies, The Guardian, 10 July. Available at http://www.theguardian.com/uk/2006/jul/10/arts.artsnews (accessed 27 February 2013).

Kearns, R. and Berg, L. (2009) Proclaiming place: Towards a geography of place name pronunciation, in: L.D.Berg and J.Vuolteenaho (Eds.) Critical Toponymies: The Contested Politics of Place Naming, pp.85-100 (Aldershot: Ashgate).

Kolås, A. (2004) Tourism and the making of place in Shangri-La, Tourism Geographies, 6(3), pp.362-278.

Kruse, R.J. (2003) Imagining Strawberry Fields as a place of pilgrimage, Area, 35(2), pp.154-162.

Kruse, R.J. (2005) The Beatles as Place Makers: Narrated Landscapes in Liverpool, England, Journal of Cultural Geography, 22(2), pp.87-114.

Haldrup, M. and Larsen, J. (2006) Material cultures of tourism, Leisure Studies, 25(3), pp.275-289.

Hannam, K. and Knox, D. (2010) Understanding Tourism: A Critical Introduction (London: Sage).

McCabe, S. (2002) The tourist experience and everyday life, in: G.M.S. Dann (Ed.) The Tourist as a Metaphor of the Social World, pp.61-75 (Wallingford: CABI).

MacCannell, D. (1976) The Tourist: A New Theory of the Leisure Class, (revised edition 1989) (New York: Schocken Books).

MacCannell, D. (1999) The Tourist: A New Theory of the Leisure Class (Second Edition), (Berkeley: University of California Press).

Mair, H. (2009) Searching for a New Enterprise: Themed tourism and the re-making of one small Canadian community, Tourism Geographies, 11(4), pp.462-483. 
Martin, H. (2010) Golden milestones for the Hollywood Walk of Fame, Los Angeles Times, 6 February. Available at http://articles.latimes.com/2010/feb/06/business/la-fi-walk-of-fame62010feb06 (accessed 27 February 2013).

Morgan, M. (2006) State park names: implications for tourism marketing, Tourism Analysis, 11(1), pp.71-74.

Morgan, N. and Pritchard, A. (2005) On souvenirs and metonymy: Narratives of memory, metaphor and materiality, Tourist Studies, 5(1), pp.29-53.

Peters, K. (2011) Negotiating the 'place' and 'placement' of banal tourist souvenirs in the home, Tourism Geographies, 13(2), pp.234-256.

Prentice, R. (1994) Heritage: A key sector of the 'new' tourism, in: C.Cooper and A. Lockwood (Eds.) Progress in Tourism, Recreation and Hospitality Management, Volume 5, pp.309-324 (Chichester: Wiley).

Ramsay, N. (2009) Taking-place: Refracted enchantment and the habitual spaces of the tourist souvenir, Social and Cultural Geography, 10(2), pp.197-217.

Roesch, S. (2009) The Experience of Film Location Tourists (Clevedon: Channel View).

Rojek, C. (1993) Ways of Escape (Basingstoke: Macmillan).

Rojek, C. (1997) Indexing, dragging and the social construction of tourist sights, in: C.Rojek and J.Urry (Eds.) Touring Cultures: Transformations of Travel and Theory, pp.52-74 (London: Routledge).

Rose-Redwood, R. (2011) Rethinking the agenda of political toponymy, ACME: An International E-Journal for Critical Geographies, 10(1), pp.34-41.

Rose-Redwood, R., Alderman, D. and Azaryahu, M. (2010) Geographies of toponymic inscription: New directions in critical place-name studies, Progress in Human Geography, 34, pp.453-470.

Rose-Redwood, R. and Alderman, D. (2011) Critical interventions in political toponymy, ACME: An International E-Journal for Critical Geographies, 10(1), pp.1-6.

Sather-Wagstaff, J. (2011) Heritage that Hurts: Tourists in the Memoryscapes of September 11 (Walnut Creek: Left Coast Press)

Shaw, G. and Williams, A.M. (2004) Tourism and Tourist Spaces (London: Sage).

Shoval, N. (2013) Street naming, tourism development and cultural conflict: the case of the Old City of Acre/Akkp/Akka, Transactions of the Institute of British Geographers, In Press.

Swanson, K.K. and Timothy, D.J. (2011) Souvenirs: Icons of meaning, commercialization and commoditization, Tourism Management, 33(3), pp.489-499. 
Urry, J. (1990) The Tourist Gaze: Leisure and Travel in Contemporary Societies (London: Sage).

Urry, J. and Larsen, J. (2011) The Tourist Gaze 3.0 (London: Sage).

Vuolteenaho, J. and Berg, L. (2009) Towards critical toponymies in: L.Berg and J.Vuolteenaho (Eds.) Critical Toponymies: The Contested Politics of Place Naming, pp.1-18 (Aldershot: Ashgate). 